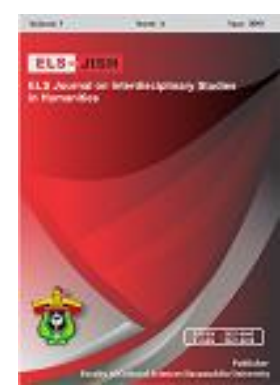

ELS-JISH

ELS Journal on Interdisciplinary Studies on Humanities

Volume 2 Issue 4, 2019

ISSN (print) : 2621-0843

ISSN (online) : 2621-0835

Homepage : http://journal.unhas.ac.id/index.php/jish

\title{
Assertive Illocutionary Act Adapted in Donald Trump's Political Speech: A Pragmatic Study
}

\author{
Reski Ramadhani ${ }^{1}$, Lia Maulia Indrayani ${ }^{2}$, Ypsi Soeria Soemantri ${ }^{3}$ \\ 1 reski18003@mail.unpad.ac.id
}

\begin{abstract}
This research is intended to discuss the illocutionary acts used in a speech mainly assertive. The writer attempts to analyze the categories of assertive illocutionary act occurs in the utterances of Donald Trump's political speech in last America's general election. This is a case study that employed a qualitative method with a descriptive approach. The writer uses Ancont software to classify the data. The function of this software is to observe the frequent words occur in the data. Then, it shows that the total number of words that occurred in Donald Trump's speech is 3046 words. Through those numbers, there are 901 types of words. However, the data used is only the open classes instead of the closed class words or grammatical category. After reducing the data, the five frequent words which are categorized as an open class appeared are 'job', 'is', 'new', 'American', and 'are'. In this case, the data are analyzed based on the frequents words and the writer also reduces the data which are not categorized as assertive illocutionary acts. From the data analysis, it reveals that the categories of assertive illocutionary acts mostly appeared in Donald Trump's political speech are statement of fact and assertion. Then, the dominant category used in the speech is a statement of fact containing a convincing. It can be concluded that most of the utterances used by Donald Trump are, besides attempting to represent himself, to convince the citizens supported by some facts about the issue that he believes to be the case in order to establish a positive perspective toward his arguments.
\end{abstract}

Keywords: Pragmatics, Speech acts, Illocutionary acts, Assertive

How to cite: Ramadhani, R., Indrayani, L. M., Soemantri, Y. S. (2019). Assertive Illocutionary Act Adapted in Donald Trump's Political Speech: A Pragmatic Study. ELS Journal on Interdisciplinary Studies in Humanities, 2 (4), 493-498

\section{Introduction}

Language is the most important part of human life. Without language, people are not able to express their thoughts, emotion, and other intentions or purposes. Furthermore, when they begin to talk by using a language, they produce utterances in a particular situation. According to Richards \& Schmid (2002), an utterance is a unit of speech analysis that has been defined in various ways but it contains a sequence of words within someone's talk. An utterance produced by the speaker should be understood by the hearer in order to deliver the message successfully. Besides, it is also important to know the context of the utterances because people do not only utter something directly but they also sometimes have an intention or imply something behind their utterances. The field of study which discusses this case is pragmatics.

\footnotetext{
${ }^{1,2,3}$ Universitas Padjadjaran, Indonesia 
Pragmatics deals with the study of meaning as communicated by a speaker (or writer) and interpreted by a listener (or a reader) (Yule, 1996). This study is necessary in order to help the hearer in communication to interpret what the speaker means in a particular context and how the context influences what is said. However, communication is sometimes not always successful because the hearer is misinterpretation what the speaker says in an utterance. Therefore, people have to be able to indicate what people's intentions to produce an utterance based on the context. When people produce the utterances by giving the context, they perform actions such as warning, informing, commanding, asserting, etc. This action is called a speech act.

Speech act occurs in a language mainly in communication. It is realized by a certain condition and can determine the meaning of an utterance. In addition, the speech act is an action performed by people via utterances such as an apology, complaint, compliment, invitation, promise, or request (Yule, 1996). Toolan (1997) also states that speech acts refer to what is done when something is said. In addition, Listya \& Novitasari (2015) argues that this term occurs because the speaker does not merely state a speech, but there is an implicit meaning in the utterances produced by the speaker. It means that people do not only produce utterances including grammatical structures or words, but they also have a communicative intention in their utterances that should be interpreted by the hearer. The speaker immensely expects that the hearer is able to understand the intention given by the speaker.

According to Cruse (2004), speech acts are divided into three, namely locutionary acts, illocutionary acts, and perlocutionary acts. A locutionary act is the basis of utterance which produces a meaningful linguistic expression. Meanwhile, illocutionary acts refer to the intended meaning of the utterance made by the speaker. Illocutionary acts are the part of speech act used to get some communicative intentions which consist of asking, ordering, suggesting, requesting, informing, advising, and greeting (Searle, 2005). There are five types of illocutionary acts in the speech act, those are assertive, commissive, directive, expressive, and declarative (Cruse, 2004). Then, perlocutionary acts are the effect of the utterances on the hearer. These types of speech act indicate various functions in the utterance, for instance, exchanging factual information, intellectual information, emotional attitudes, moral attitudes, persuasion, and socializing (Searle, 2005). However, this study focuses on the assertive illocutionary act which Yule (1996) has a different term called representative.

The important of the language is also beneficial for politicians. Beard (2002) states that politicians use language as speeches, written texts, broadcasts in order to inform and persuade citizens about important issues. They do not only provide certain information but also have intentions to make people believe what things are proposed by them. One of the famous politicians in America is Donald Trump. He is the current president of The United State since he won over voters in last America's general election. Speech can be a tool for convincing people or establishing a social relationship, expressing feelings, providing an idea, policies, and programs in any society. Regarding this issue, the writer is fascinated to analyzed the language mainly speech act used by Donald Trump in his speeches during the campaign.

There are some related studies used by the writer in this research. First, Saputro (2015) conducted research and the result showed that the dominant speech act mainly illocutionary act used by the president of Indonesia, Jokowi Dodo, was assertive which has the perlocutionary effect where the audience jointly works with Jokowi especially in the business sectors. Meanwhile, Listya \& Novitasari (2015) also conducted a similar topic with the previous researcher which analyzed the illocutionary speech act occurred in Jokowi's speeches and the result also showed that the most illocutionary speech act which appears in the speech was assertive and the category is collaborative. Dewi, Rajeg, \& Netra (2016) also analyzed the commissive and representative occurring in Steel's Cottage and the result 
showed that the most category which exists in the novel is requesting. However, as the research gap, this research has two differences compared to the previous researches. First, this research tries to analyze the speech act mainly illocutionary act occurring in Donald Trump's speeches. Second, this research does not analyze all types of illocutionary acts, but this only analyzes the assertive illocutionary acts which appear in the speech. Therefore, the aim of this research is to analyze the assertive illocutionary acts used by the current president of America, Donald Trump. There are two formulations of the study: what are the categories of assertive illocutionary acts found in Donald Trump's speech? and What is the dominant type of the assertive illocutionary acts found in Donald Trump's speech?

\section{Method}

This study uses qualitative research with a descriptive technique. Creswell (2012) states that qualitative research is a good way to address a research problem in which you do not know the variables and need to explore. In addition, According to Saldana (2011), qualitative research is an umbrella term for a wide variety of approaches to and methods for natural social life. Qualitative research does not use statistical data or numbering in analyzing the data. Qualitative research concerns the quality of the data and refers to the process of data in which this process cannot be analyzed or measured by using an experiment. The qualitative research also concerns the nature of the reality of the data, social relationship between the researcher and the object of the research. The object of this research is taken from Donald Trump speech in a political issue, as Beard (2002) stated that language has useful for many purposes, especially for politicians. Politicians use language to engage the citizen to something or convince them about the issue that they believe. The writer wants to analyze the assertive illocutionary acts used by Donald Trump in his speech during the political campaign in order to how he convinced the citizen to vote him as president.

In collecting the data, the writer uses the Ancont software. Through this software, the writer observes the frequent words that occur in the speech. the function of this software is to observe the frequent words occur in the data source through the 'concordance hits'. In order to search the context more, the writer uses 'file view' tool. The column of 'cluster/N-grams' also can be used to observe the frequent words which come along with the 'collocates'. 'Wordlist' is used to see the number of words occurred in the speech containing Donald Trump's speech. The total amount of words occurred in Donald Trump's speech is 3046 words. Though those amounts, there are 901 types of words. The most frequent words appeared in the article 'the' appearing as much as 142 times. Then, the second word which appears is conjunction 'and' as much as 117 times. But, in this case, the data used is the open class and not the closed class words or grammatical category. After reducing the data, the five frequent words which are categorized as an open class are 'job', 'is', 'new', 'American', and 'are'. The data are analyzed based on the frequents words and the writer also reduces the data which are not categorized as assertive illocutionary acts.

\section{The Analysis of Results}

To analyze the data, the writer uses the Searles and Cruse's theory. The writer reduces the data which is not classified as an assertive illocutionary act. Then, the writer analyzed the data based on the category of assertive illocutionary acts whether it is informing, convincing, questioning, describing or stating.

\subsection{The Analysis of Data 1}

"The jobs have stripped from this community, and its infrastructure has collapsed. In 1970, there were more than 80,000 people in Flint working for GM - today it is less than 8,000 ." 
From the utterance above, the speech consists of the assertive of informing. The speaker gives the information to the listener about the condition in America nowadays. The speaker believes that the government took the jobs from the community and some of the infrastructures had failed because and it can be seen from the data given where no more than 8.000 people who work for GM if it is compared to 1970. This is considered as informing because Mr. Trump wants people to know about the crisis happening in America. It also contains a fact or truth, if the jobs which are available less than the previous one, it indicates the total number of jobs decreases. Therefore, he believes that this issue is based on the fact.

\subsection{The Analysis of Data 2}

"Jobs can stop leaving our country, and start pouring in and to accomplish them, we must replace the present policy of globalism."

The utterance above is considered as assertive because it contains something true. Mr. Trump states that jobs can be back for the people who haven't get a job. It can only be accomplished if the policy of globalism is changed. It is something that he believes as the solution to this issue. In addition, it may be true or logic that one of the ways to make the job available is to change the policy and it contains a fact. This assertive illocutionary act is categorized as convincing because Mr. Trump tries to convince the citizens that the job will be available if the way which he believes is implemented.

\subsection{The Analysis of Data 3}

"If we lower our taxes, remove destructive regulations, unleash the vast treasure of American energy, and negotiate trade deals that put America first, then there is no limit to the number of jobs we can create and the amount of prosperity we can unleash."

The datum above is classified as assertive because Mr. Trump says something true. He believes that the other solutions to make every people in his country have a job is to lower the taxes, omitting the destructive regulation, smoothing the huge energy that the Americas have. It is a logic statement given by him because the factor that makes many of jobs are lost because the tax which is ruled is so high, a bad regulation, the poor maintaining of energy source, and the negotiations which do not bring the advantage for the country. It means the utterances give the statement of fact and this assertation is categorized as convincing because he tries to convince the citizens that this solution can bring a positive impact on the American economy in the future. He also uses the modality 'can' which means it indicates a possibility.

\subsection{The Analysis of Data 4}

"Too many of our leaders have forgotten that it's their duty to protect the jobs, wages, and well-being of American workers before any other consideration."

This utterance is also considered as assertive because Mr. Trump says the utterance, besides contains an implied meaning, to express truth for the hearer. From the utterance, we know that the duty of the leaders of the country is to give the welfare for their people and to develop all sectors such as educations, economies, infrastructures, etc. in order to make their people comfortable to stay in their country. In addition, the most important aspect that the leader must be concern is the availability of the jobs so that the people can live their life properly and they also have to provide a guarantee to protect people when they work and Mr. Trump wants to emphasize it. These statements contain the truth or fact and he believes that the leader of his country has forgotten this obligation. The assertive given by Mr. Trump is categorized as informing because he wants to give the information to the hearers how their leaders treat them and do not give them the job guarantee. 


\subsection{The Analysis of Data 5}

"By lowering rates, streamlining deductions, and simplifying the process, we will add millions of new jobs."

The data above showed that it is one of the ways which Mr. Trump believes as the solution for the economic challenges in his country. It is also considered as assertive because Mr. Trump says something true or it can be a fact and the utterances also contain an implied meaning. It is true because one of the factors that impose the citizens is the high rates implemented by the government. It will give pressure on society which also influences the availability of the jobs. Furthermore, streamlining deduction and the process which is simple will make the jobs easier to gain. Therefore, Mr. Trump produces the utterances containing a fact. He also has an intention to convince people in order to believe in his solutions. Thus, the category of the assertive illocutionary acts used by Mr. Trump is convincing.

\subsection{The Analysis of Data 6}

"That's why I believe it is time to establish a national goal of reaching $4 \%$ economic growth."

The utterance contains an assertive because Mr. Trump asserts something that he believes to be a case. He obviously uses the performative verb "believe" which indicates something that he sees to be true. He believes that by extending the economic growth into 4 $\%$, it will constitute the national goal mainly in the availability of the jobs. It is categorized as stating a statement.

\subsection{The Analysis of Data 7}

"Right now, 92 million Americans are on the sidelines, outside the workforce, and not part of our economy."

This utterance also considered an assertive illocutionary act because it consists of what the speaker believes. From his statement, he thinks that the workers that should belong to America, now, they are not part of them again or they are not in the right place. It can be indicated that it is what he believes which is supported by the data he has. He wants to give an assertation about the condition of America economics today. It is as if the fact that people may refer to and he tries to raise the issue by giving the number which can indicate appropriate information. This assertive is categorized as stating because it is just what he thinks to be true.

\subsection{The Analysis of Data 8}

"If we save just one penny of each federal dollar spent on non-defense, and nonentitlement programs, we can save almost \$1 trillion over the next decade again this is spending that does not touch defense, and that does not touch entitlements."

The data above also show an assertive because Mr. Trump says something that may be true. He tries to give a solution in order to save the economic challenge in the future. What he believes is if the country can manage the cash out which spent on unnecessary things or non-profit program, the country can be able to save more money for other goals. The utterances produced by Mr. Trump are something true because, like the illustration, when we spent our money on useless things, we do not get anything, but if we spent our money for the obvious purposes, we can get many things. In this case, Mr. Trump tries to convince the citizens that this is one of the keys to make the economics grows in the future. The category of the assertive given by Mr. Trump is convincing. 


\section{Conclusion}

Based on the discussion above, it can be concluded that most of the statement used by Mr. Trump in his speech contains an assertive illocutionary act. Then, most of the assertive containing the statement of fact that he believes to be the case or a true. The utterances produced to try to convince the American that what he believes can happen in the future if he is chosen as the leader. In this research, the writer analyses eight data that have been chosen through reduction which is classified as an assertive illocutionary act. The result of the analysis shows that there are only two categories of assertive illocutionary acts that occur in the speech, statement of fact containing a convincing and assertation containing stating information. The writer finds that statement of fact containing a convincing is the dominant category occurs in the speech of Donald Trump. It is quite reasonable considering the purpose of this speech is to convince and inform the listener about the vision and mission of Donald Trump is promoting his self as the great leader in the future that can make, as his quote, "America great again".

\section{Acknowledgments}

We thank our colleagues from Padjadjaran University who provided insight and expertise that greatly assisted the research, although they may not agree with all of the interpretations/conclusions of this paper. We also thank the lecturers of Padjadjaran University especially Linguistic Study for comments that greatly improved the manuscript. We would also like to show our gratitude to our other colleagues for sharing their pearls of wisdom with us during the course of this research, and we thank the reviewers for their socalled insight.

\section{References}

Beard, A. (2002). The Language of Politics. London: Routledge.

Creswell, J. W. (2012). Educational research. Pearson.

Cruse, A. (2004). Meaning in Language: An Introduction to Semantics and Pragmatics. New York: Oxford University Press.

Dewi, A. A. P. R., Rajeg, I. M., \& Netra, I. M. (2016). Commissive and Expressive Illocutionary Acts and Their Intended Meaning In Steel's The Cottage. 16(3), 7-14.

Listya, A., \& Novitasari, N. F. (2015). The Analysis of Illocutionary Acts in the President Joko Widodo's Speech. 6(1).

Richards, J. C., \& Schmid, R. W. (2002). Longman Dictionary of Language Teaching and Applied Linguistics. Retrieved from https://books.google.co.id/books?id=kqSsAgAAQBAJ\&printsec=frontcover\&source=gb s_ge_summary_r\&cad $=0 \# v=0$ nepage $\& q \& f=f a l s e$

Saldana, J. (2011). Fundamentals of Qualitative Research. Oxford, New York: Oxford University Press.

Saputro, E. P. N. (2015). The Analysis of Illocutionary Acts of Jokowi's Speeches. Sanata Dharma University, Yogyakarta.

Searle, J. R. (2005). Expression and Meaning: Studies in the Theory of Speech Acts. Cambridge: Cambridge University Press.

Toolan, M. (1997). Working With Text: A Core Book For Language Analysis. London: Routledge.

Yule, G. (1996). Pragmatics. New York: Oxford University Press. 